\title{
Expression of basic fibroblast growth factor in synovial tissues from patients with rheumatoid arthritis: detection by immunohistological staining and in situ hybridisation
}

Munetoshi Nakashima, Katsumi Eguchi, Takahiko Aoyagi, Izumi Yamashita, Hiroaki Ida, Masahiro Sakai, Hironori Shimada, Yojiro Kawabe, Shigenobu Nagataki, Takehiko Koji, Paul K Nakane

\begin{abstract}
Objective-The distribution and production of basic fibroblast growth factor (bFGF) was examined on the synovium from patients with rheumatoid arthritis (RA) and osteoarthritis (OA).

Methods-The localisation of bFGF was determined by an immunohistochemical staining procedure using anti-bFGF monoclonal antibody. The expression of bFGF mRNA was detected by nonradioactive in situ hybridisation using bFGF antisense oligo DNA.

Results-The bFGF was found in the synovial lining cell, sublining stromal fibroblast-like cells, and vascular endothelial cells from patients with $R A$ and OA. Little or no bFGF was found in noninflamed synovium. Immunostaining of bFGF in the synovial cells was more extensive and intense in synovium of patients with RA than that of patients with OA. The nuclei of the synovial lining cell layer were also immunostained. These nuclear staining were more intense in the lining cell layer from RA patients with moderate or severe proliferation of synovial cells than in $R A$ patients with mild proliferation. The bFGF mRNA was also detected in the synovial lining cell layer of the inflamed synovium.
\end{abstract}

First Department of Internal Medicine, the Third Department of Anatomy, Nagasaki University School of Medicine, Nagasaki and Department of Orthopedics, Ureshino National Hospital, Saga, Japan

M Nakashima

K Eguchi

T Aoyagi

I Yamashita

H Ida

M Sakai

H Shimada

Y Kawabe

$S$ Nagataki

T Koji

P K Nakane

Correspondence to:

Professor Shigenobu

Nagataki,

First Department of Internal

Medicine, Nagasak

University School of

Medicine, 1-7-1 Sakamoto,

Nagasaki City, Nagasaki 852,

Japan.

Accepted for publication

23 September 1993

Rheumatoid arthritis (RA) is a disease of joints with polyarticular inflammation, destruction of bones and cartilage, and ankylosis. The inflamed synovium of RA is characterised by pronounced hyperplasia of the synovium, angiogenesis and inflammatory cell infiltration in the synovium. Transforming growth factor$\beta$ (TGF- $\beta),{ }^{12}$ platelet-derived growth factor $(\mathrm{PDGF})^{3-5}$ and acidic as well as basic fibroblast growth factor (FGF) have been shown to regulate the proliferation of human synovial fibroblasts. ${ }^{267}$ Moreover, some of these growth factors have turned out to be the actual products of synovial cells themselves; PDGF protein as well as mRNA is detected in the synovial cells from patients with RA. ${ }^{3}$

Basic FGF (bFGF) is a 146 amino acid protein with molecular weight of 18000 and believed to be an autocrine and/or paracrine growth and angiogenesis factor, and is released extracellulary. The factor lacks the signal peptide sequence for secretion. ${ }^{8}$ The pathway of bFGF secretion has been the focus of studies, but has not been clarified. ${ }^{910}$ The role of bFGF (and acidic FGF) for synovial proliferation has been studied in vivo and in vitro. The supernatant of cultured synovial cells contained mitogenic activity, and the biological properties were identical to bFGF. ${ }^{6}$ Furthermore, the synoviocytes express bFGF mRNA. These results suggest that synoviocytes themselves produce bFGF. ${ }^{6}$

Our previous study also indicated that the supernatant of mechanically-wounded endothelial cells and synovial cells (by scraping from the substratum) had the proliferative activity of endothelial cells or synovial cells themselves, and it was regarded as bFGF based upon evidence that the factor binds to heparinsepharose column, and is eluted by washing with $2.0 \mathrm{M} \mathrm{NaCl}$. Furthermore, protein sulphate (which blocks the interaction of FGFs and their receptors) and anti-bFGF antibody inhibited the mitogenic activity of the supernatant. ${ }^{11}$ To investigate what type of cells in the synovium produce bFGF in patients with $\mathrm{RA}$ and OA, the expression of bFGF protein and mRNA was examined by means of immunohistochemistry and in situ hybridisation, respectively. Finally, we studied the relationship between the expression of bFGF and the disease activity of patients with RA.

\section{Materials and methods}

PREPARATION OF SYNOVIAL TISSUES obtained from patients who were undergoing total knee joint replacement or synovectomy. Fifteen tissues were from patients with RA who met the American Rheumatology Association 1987 revised criteria for the classification of RA, ${ }^{12}$ and five were from patients with OA. Five normal synovial tissues were also obtained from patients who were having corrective surgery with joint trauma. The patients are
Specimens of inflamed synovium were 
Table 1 Profiles of 6 active and 9 inactive patients with $R A$

\begin{tabular}{lccllll}
\hline & $\begin{array}{c}\text { Patient } \\
\text { number }\end{array}$ & Age & Sex & Class & Stage & Grade $^{\star}$ \\
\hline Active patients & 1 & 48 & F & 3 & IV & 1 \\
& 2 & 71 & F & 2 & III & 1 \\
& 3 & 76 & F & 3 & III & 2 \\
& 4 & 59 & F & 3 & IV & 2 \\
& 5 & 61 & F & 2 & III & 3 \\
Inactive patients & 6 & 59 & F & 2 & I & 3 \\
& 7 & 51 & F & 2 & I & 1 \\
& 8 & 55 & M & 2 & III & 1 \\
& 9 & 46 & F & 2 & IV & 1 \\
& 10 & 77 & F & 3 & III & 1 \\
& 11 & 41 & F & 2 & III & 1 \\
& 12 & 56 & F & 3 & III & 2 \\
& 13 & 44 & F & 2 & III & 2 \\
& 14 & 40 & M & 2 & III & 2 \\
& 15 & 65 & F & 3 & III & 3 \\
\hline
\end{tabular}

${ }^{\star}$ Grade: This score shows the local inflammatory grade at the time of arthroscopic examination or surgical operation.

described in table 1 . The patients with RA were divided into 2 groups according to their general inflammatory activity: a) duration of morning stiffness $\geqq 45$ minutes; b) erythrocyte sedimentation rate $\geqq 28 \mathrm{~mm} /$ hour; c) the number of tender joints $\geqq 9$, and d) the number of swollen joints $\geqq 6$. Six patients fulfilled at least three of the four criteria and were classified as the active group. Nine patients were classified as the non-active group. Furthermore, by arthroscopic examination, the local inflammatory activity was graded according to the degree of synovial proliferation of each joint: grade 1 - mild synovial proliferation; grade 2 - moderate synovial proliferation; and grade 3 - severe synovial proliferation. The grades of the local inflammatory activity were evaluated by the same rheumatologist. All patients had been administered a non-steroidal anti-inflammatory drug (NSAID). Five of six active patients had been taking predonisolon $(5.0 \mathrm{mg} /$ day), and four had been taking methotrexate $(5.0 \mathrm{mg} /$ week $)$. In the non-active group, two of nine patients had been administered predonisolon $(2.5 \mathrm{mg} /$ day $)$, two had D-penicillamin $(100 \mathrm{mg} /$ day $)$, and another had methotrexate $(5.0 \mathrm{mg} /$ week). No patients had been injected with intra-articular corticosteroids.

OLIGODEOXYNUCLEOTIDE (OLIGO-DNA) PROBES Three repeated sequences of A-T-T followed by an antisense sequence corresponding to 3-47 region of human bFGF mRNA (table 2$)^{13}$ and terminated by two more repeated sequences of A-T-T was synthesised using a DNA synthesiser (Applied Biosystems, Tokyo, Japan). As a control DNA probe, an antisense sequence corresponding to $136-180$ region of rat prolactin mRNA $^{14}$ was made with the same design of A-T-T repeats as that of the specific probe. The 5' and $3^{\prime}$ terminal adjacent thymines were dimerised by ultraviolet irradiation by a dose of 10000 joules $/ \mathrm{m}^{2}$ as described previously. ${ }^{15}$ To evaluate the probe specificity, we carried out the dot-blot hybridisation where sense or antisense strand coding for the gene amino 1-17 of human bFGF, which was fixed onto nitrocellulose membranes at various quantities was hybridised with T-T dimerised $\mathrm{bFGF}$ antisense oligoDNA. As a result, $10 \sim 50 \mathrm{pg}$ of sense oligoDNA was specifically detected by the same system used for in situ hybridisation (data not shown).

\section{IN SITU HYBRIDISATION}

Synovial tissues from seven patients with RA, three with $\mathrm{OA}$, and three with traumatic joint disease were processed for in situ hybridisation. In situ hybridisation method using thymine-thymine (T-T) dimerised oligo-DNA was carried out as reported elsewhere. ${ }^{15} 16$ Briefly, fresh synovial tissues were fixed in $4 \%$ paraformaldehyde solution (Wako, Osaka, Japan) for eight hours at $4^{\circ} \mathrm{C}$, and washed with phosphate buffered saline (PBS) for 15 hours. The fixed tissuies were embedded in OCT compound and quickly frozen at $-80^{\circ} \mathrm{C}$. The frozen blocks were sectioned at $6 \mu \mathrm{m}$ in thickness and mounted on to the glass coated with gelatin ${ }^{15}$ and dried for 15 hours at $45^{\circ} \mathrm{C}$. After rehydration in PBS, endogenous peroxidase was inactivated with $0.3 \% \mathrm{H}_{2} \mathrm{O}_{2}$ in methanol. The sections were treated with $0 \cdot 2$ $\mathrm{N} \mathrm{HCl}$ for 20 minutes and were hybridised overnight at $37^{\circ} \mathrm{C}$ with $30 \mu$ l of hybridisation mixture containing $10 \mathrm{mM}$ Tris- $\mathrm{HCl}, 1 \mathrm{mM}$ EDTA, $0.6 \mathrm{M} \mathrm{NaCl}, 1 \times$ Denhardt's solution, $40 \%(\mathrm{~V} / \mathrm{V})$ deionised formamide, $125 \mu \mathrm{g} / \mathrm{ml}$ sonicated salmon sperm DNA, $250 \mu \mathrm{g} / \mathrm{ml}$ yeast tRNA, $10 \%$ dextran sulfate, and $2 \mu \mathrm{g} / \mathrm{ml}$ T-T dimerised probe DNA. After the hybridisation, the sections were washed with $50 \%$ formamide in $2 \times \mathrm{SSC}$ at $37^{\circ} \mathrm{C}$ five times for one hour each, and washed twice with $2 \times$ SSC for 15 minutes each. After the washes, sections were incubated with non-immunoreactive goat IgG for one hour to block the non-specific binding of $\operatorname{IgG}$, and then reacted with rabbit anti-T-T dimer for 15 hours. After one hour wash with PBS, the sections were reacted with $\mathrm{HRP}$-conjugated anti-rabbit goat IgG, and washed with PBS for one hour. The sites of HRP were visualised using 3,3'-diaminobenzidine (Dojindo, Kumamoto, Japan) in the presence of nickel and cobalt ions. ${ }^{15}$ Tissues were not counterstained. The intensities of staining were subjectively divided into 4 grades. $(-)$ : no staining; $(+-)$ : mild; $(+)$ : moderate; $(++)$; strong staining.

Table 2 The oligodeoxy nucleotide DNA probe sequence of human basic FGF used for this study bFGF sequence : $5^{\prime} \quad$---CGCAGGGACC-ATG-GCA-GCC-GGG-AGC-ATC-ACC-ACG-CTG-CCCAntisense probe : $3^{\prime}$ TTA-TTA-TTA-C-CGT-CGG-CCC-TCG-TAG-TGG-TGC-GAC-GGG- 

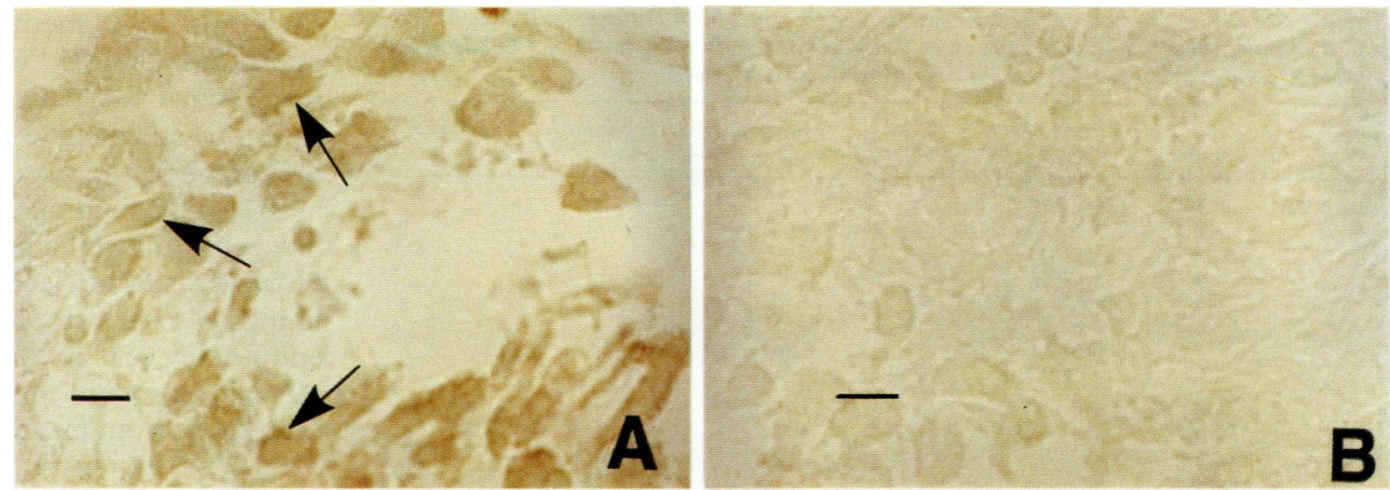

Figure 1 The expression of $m R N A$ of $b F G F$ by in situ hybridisation. A: staining of synovial tissue from $R A$ patient with $b F G F$ antisense oligo DNA probe. Positive stainings were found in the cytoplasm of synovial lining cells (arrow). $B$ : synovial tissue stained with control DNA probe. No positive staining was detected. Bar $=10 \mu \mathrm{m}$.

\section{IMMUNOHISTOCHEMISTRY}

Synovial tissue sections from fifteen RA patients, five OA patients, and five traumatic synovial specimens were stained immunohistochemically. Some were the same material as used for the in situ hybridisation. The frozen sections were mounted on to the glass slide coated with egg albumin. Endogenous peroxidase was inactivated by emersing the section in $3 \% \mathrm{H}_{2} \mathrm{O}_{2}$ solution in distilled water (DW) for 15 minutes. The sections were first incubated with non-immune rabbit IgG, then reacted with neutralising mouse anti-bFGF antibody (bFM-1) ${ }^{17}$ for one hour at room temperature. The reacted mouse antibody was then localised by the peroxidase labelledstreptavidin-biotin method using a Histofine staining kit (Nichirei, Tokyo, Japan). The colour was developed using 3,3'-diaminobenzidine and $\mathrm{H}_{2} \mathrm{O}_{2}$, and were counter-stained with hematoxylin. The intensities of staining were subjectively divided into 4 grades. $(-)$ : no staining; (+-): mild; (+): moderate; (++); strong staining.

\section{Results}

IN SITU HYBRIDISATION

bFGF mRNA was detected by in situ hybridisation. In the RA synovium, bFGF mRNA was localised to the lining cells (fig 1A). In seven synovial tissues with RA, all tissues were stained for bFGF mRNA in the lining cells. However, six tissues were stained in the fibroblast-like cells and two were in the

Table 3 Expression of bFGF-mRNA on synovial tissues stained in in situ hybridisation

\begin{tabular}{lclll}
\hline & $\begin{array}{l}\text { Patient } \\
\text { number }\end{array}$ & $\begin{array}{l}\text { Lining } \\
\text { cells }\end{array}$ & $\begin{array}{l}\text { Fibroblastic } \\
\text { cells }\end{array}$ & $\begin{array}{l}\text { Endothelial } \\
\text { cells }\end{array}$ \\
\hline RA synovium Active & 1 & ++ & + & - \\
& 2 & + & + & + \\
Inactive & 4 & + & + & - \\
& 5 & + & + & + \\
OA synovium & 7 & + & + & - \\
& 8 & + & + & - \\
Non-inflammatory synovium & 12 & ++ & - & + \\
& 1 & ++ & - & - \\
& 2 & - & - & - \\
& 5 & - & - & - \\
& 1 & - & - & - \\
\hline
\end{tabular}

*: The expression of bFGF mRNA in lining cells was exclusively restricted to the cytoplasm. endothelial cells (table 3 ). In lining synovial cells, positive stainings were restricted to the cytoplasm, and no differences in the staining intensity were observed between active and inactive groups (table 3 ). In OA synovium, the lining cells and vascular endothelial cells were stained for bFGF mRNA in one of three specimens (table 3 ). When the sections were hybridised with the control probe, no staining was observed (fig 1B). Also, no staining of bFGF mRNA was detected on noninflammatory synovium.

\section{IMMUNOHISTOCHEMICAL STAINING}

Distribution of bFGF in the synovium was examined by an immunohistochemical method using anti-bFGF monoclonal antibody. The data on the immunostaining are summarised in table 4. All RA and OA sections which were reacted with the control antibodies were negative. Nuclear and/or cytoplasmic staining of bFGF was found in synovial lining cells from all RA patients; and in the vascular endothelial cells in eight of $15 \mathrm{RA}$ patients. The immunostaining of the synovial lining cells was more intense than the vascular endothelial cells. A few patients with RA had positive staining for bFGF in the infiltrated mononulear cells. A representative synovial tissue sections from patients with RA and OA were shown in fig 2 . Diffuse and intense cytoplasmic staining was detected within the synovial lining cell layer (fig 2A). bFGF staining was also observed in the vascular endothelial cells, however, basement membranes and extracellular matrixes associated with these cells seemed negative (fig $2 \mathrm{~A}$ ). In addition to the intense cytoplasmic staining, nuclear staining was also found in the synovial lining cell layer (fig 2B). Immunostaining of bFGF in the synovial lining cells and sublining fibroblastlike cells from OA patients was less intense than that from RA patients. Only two of the five OA patients had nuclear staining. However, synovial tissue sections from one patient with OA also stained strongly on the synovial lining cell layer, sublining stromal fibroblast-like cells and vascular endothelial cells (fig 2C). No staining with anti-bFGF was observed in tissue sections of normal synovium (data not shown). 
Table 4 - bFGF expression on the synovial tissues obtained from patients with $R A, O A$, and traumatic injury. The synovium from $R A$ patients are divided into 2 groups according to the systemic activity score described in Materials and methods

\begin{tabular}{|c|c|c|c|c|c|c|}
\hline & $\begin{array}{l}\text { Patient } \\
\text { number }\end{array}$ & $\begin{array}{l}\text { Lining cell } \\
\text { (Nucleus) }\end{array}$ & (Cytoplasm) & $\begin{array}{l}\text { Fibroblastic } \\
\text { cells }\end{array}$ & $\begin{array}{l}\text { Infiltrated } \\
\text { cells }\end{array}$ & $\begin{array}{l}\text { Endothelial } \\
\text { cells }\end{array}$ \\
\hline Active RA & $\begin{array}{l}1 \\
2 \\
3 \\
4 \\
5 \\
6\end{array}$ & $\begin{array}{l}- \\
+ \\
+ \\
++ \\
++ \\
++ \\
5 / 6\end{array}$ & $\begin{array}{l}++ \\
+ \\
+ \\
- \\
- \\
+ \\
4 / 6\end{array}$ & $\begin{array}{l}+ \\
+ \\
+- \\
+ \\
+ \\
+ \\
6 / 6\end{array}$ & $\begin{array}{l}- \\
- \\
- \\
- \\
\overline{-} \\
+ \\
1 / 6\end{array}$ & $\begin{array}{l}- \\
- \\
+- \\
+ \\
+ \\
+ \\
4 / 6\end{array}$ \\
\hline Inactive RA & $\begin{array}{r}7 \\
8 \\
9 \\
10 \\
11 \\
12 \\
13 \\
14 \\
15\end{array}$ & $\begin{array}{l}- \\
++ \\
+ \\
- \\
+ \\
++ \\
+ \\
+ \\
++ \\
7 / 9\end{array}$ & $\begin{array}{l}++ \\
- \\
- \\
+ \\
+ \\
- \\
++ \\
+ \\
+ \\
6 / 9\end{array}$ & $\begin{array}{l}+ \\
+ \\
+- \\
- \\
- \\
+ \\
+ \\
+- \\
+ \\
7 / 9\end{array}$ & $\begin{array}{l}- \\
- \\
- \\
+ \\
- \\
\overline{-} \\
- \\
- \\
\overline{1} \\
1 / 9\end{array}$ & $\begin{array}{l}- \\
- \\
+- \\
- \\
+- \\
+ \\
- \\
- \\
+ \\
4 / 9\end{array}$ \\
\hline $\mathrm{OA}$ & $\begin{array}{l}1 \\
2 \\
3 \\
4 \\
5\end{array}$ & $\begin{array}{l}++ \\
- \\
- \\
+- \\
- \\
2 / 5\end{array}$ & $\begin{array}{l}++ \\
+ \\
- \\
- \\
\overline{2} / 5\end{array}$ & $\begin{array}{l}++ \\
+ \\
- \\
+ \\
+ \\
4 / 5\end{array}$ & $\begin{array}{l}- \\
\bar{t} \\
+ \\
+ \\
\overline{2} / 5\end{array}$ & $\begin{array}{l}++ \\
- \\
+ \\
+ \\
+ \\
4 / 5\end{array}$ \\
\hline NOR $^{\star}$ & $\begin{array}{l}1 \\
2 \\
3 \\
4 \\
5\end{array}$ & $\begin{array}{l}- \\
- \\
- \\
- \\
\overline{0} / 5\end{array}$ & $\begin{array}{l}- \\
- \\
- \\
- \\
\overline{0} / 5\end{array}$ & $\begin{array}{l}- \\
\overline{-} \\
\overline{-} \\
\overline{-} \\
0 / 5\end{array}$ & $\begin{array}{l}- \\
\overline{-} \\
\overline{-} \\
\overline{0} \\
0 / 5\end{array}$ & $\begin{array}{l}- \\
- \\
- \\
- \\
- \\
0 / 5\end{array}$ \\
\hline
\end{tabular}

^NOR: non-inflammatory synovium

CORRELATION OF BFGF EXPRESSION WITH GENERAL ACTIVITY OF RA

bFGF expression found in the synovial tissues with RA was more intense than that with OA. To investigate the correlation between the bFGF expression and general RA activity, we separated RA patients into two groups according to the activity score described in
Materials and methods. Results are summarised in table 4 . When the synovial tissues from active RA patients were compared with those from inactive patients, there was no difference in the incidence of positive staining in the synovial lining cells, sublining fibroblastlike cells, infiltrated cells and endothelial cells. However, the nuclear staining in the synovial lining cells and cytoplasmic staining in vascular endothelial cells in synovial tissues from active RA patients were more extensive and intense than those from inactive RA patients.

\section{CORRELATION OF BFGF EXPRESSION WITH}

LOCAL INFLAMMATORY ACTIVITY

Although no significant difference was detected between the active and inactive group with RA in the incidence and intensity of bFGF expression, bFGF expression might be involved in the local inflammation and proliferation in each joints with RA. To examine this possibility, tissues from RA were divided into three grades, according to the local inflammatory grades evaluated by an arthroscopic examination, and the correlation of bFGF expression and local inflammation activity was investigated. As summarised in table 5, the nuclear staining of bFGF in the synovial lining cells and the cytoplasmic staining in the vascular endothelial cells in the grade 2 and grade 3 tissues was more intense than that in grade 1 tissues. In contrast to the nuclear staining, the cytoplasm of synovial lining cells of the grade 1 tissues had more intense staining than that of the grade 2 and grade 3 tissues.

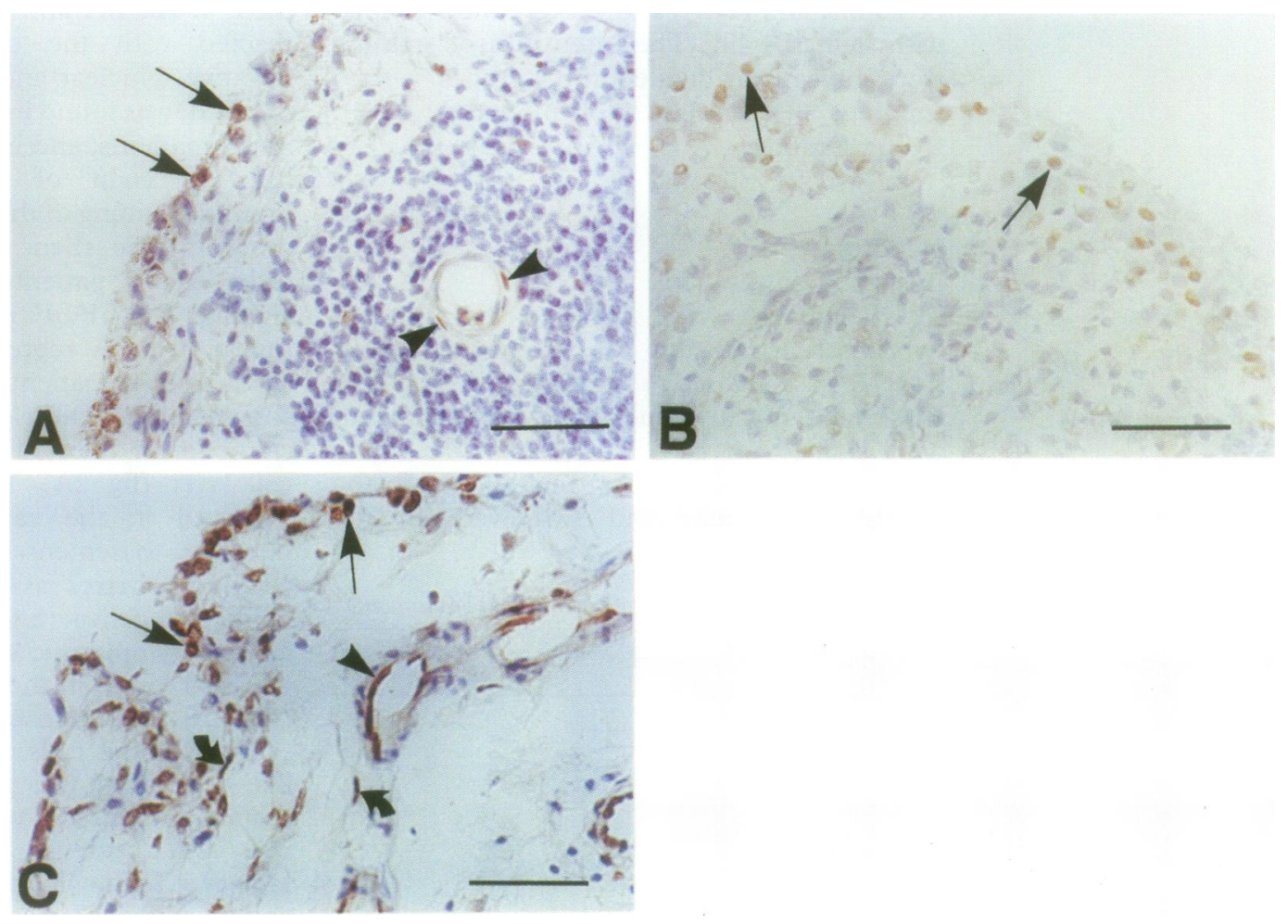

Figure 2 Immunohistochemical staining of bFGF. Basic FGF was stained by anti-bFGF monoclonal antibody (bFM-1). Positive staining was indicated by brownish block deposits. A: synovial specimen from a patient with $R A$. Positive cytoplasmic staining was found on the synovial lining cells (arrow), and the vascular endothelial cells (arrowhead). B: synovial specimen from a patient with $R A$. Positive nuclear staining was detected on the synovial lining cells (arrow). $C$ : synovial specimen from a patient with $O A$. Positive staining was found on the lining cells (arrow), fibroblast-like cell (curved arrow), and vascular endothelial cell (arrowhead). Bar $=50 \mu \mathrm{m}$. 
Table 5 The results of immunohistochemical staining classified by the local synovial proliferation score graded at the arthroscopic examination

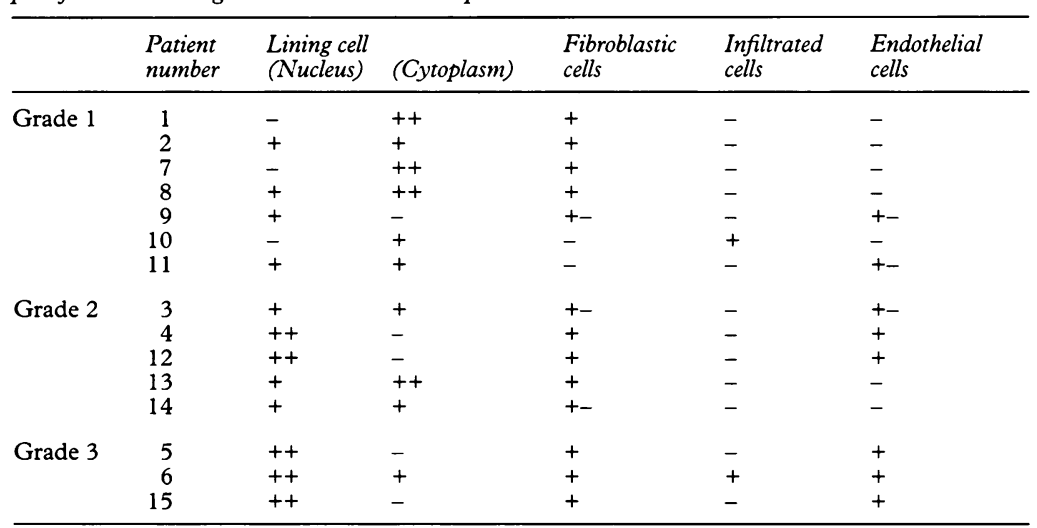

Grade 1: mild proliferation; Grade 2: moderate proliferation; Grade 3: severe proliferation.

\section{Discussion}

Rheumatoid synovium is characterised by angiogenesis, mononuclear cell infiltration, and a remarkably active proliferation of synovial cells. The proliferative synovial cells and infiltrated mononuclear cells may play a major role in the destruction of cartilage and bone in the joints. Recently, a number of studies have proposed that some growth factors such as TGF- $\beta$, PDGF, aFGF and bFGF regulate the proliferation of human synovial cells. ${ }^{1-7}$ Among them, bFGF is of particular interest, since cultured synovial cells in vitro express bFGF mRNA and bFGF protein. ${ }^{6}$ Moreover, the cells have the functionable receptor for bFGF. ${ }^{6}$

In the synovium from $\mathrm{RA}$ and $\mathrm{OA}$ patients in our study bFGF was detected immunohistochemically in the cytoplasm or nucleus of the synovial lining cells, sublining stromal fibroblast-like cells, and endothelial cells. The immunostaining of bFGF in the synovium of RA patients was more extensive and intense than that of OA patients. Especially in RA patients, the nuclei of some of the synovial lining cells were also stained for bFGF. The bFGF mRNA was detected by in situ hybridisation in the synovial lining and endothelial cells of these RA and OA patients. Conversely, neither bFGF protein nor bFGF mRNA was detectable in non-inflamed synovium obtained from traumatic joint injury. These results indicated that the synovial cells and the vascular endothelial cells contain bFGF, and bFGF is synthesised by itself, not from extracellular sources.

To clarify the relationship between bFGF expression and disease activity, we first compared bFGF expression in the synovium with active RA or non-active RA. Although there was no definite correlation between bFGF expression and general disease activity in the RA patients, when synovial tissues were graded based on the proliferative activity of the synovial cells by arthroscopic examination, a different localisation pattern of bFGF protein depending on the grades was detected. All synovial tissues with moderate or high proliferation contained stained nuclei in their synovial lining cells, whereas in low proliferative lining, bFGF was predominantly localised to the cytoplasm.
Various lines of evidence have strongly suggested the involvement of nuclear localisation of bFGF in cell proliferation; proliferating adult bovine aortic endothelial cells has already shown nuclear and nucleolar localisation of $\mathrm{bFGF},{ }^{18}$ the nuclei of the quiescent confluent endothelial cells are void of bFGF, and two hours after the addition of bFGF, bFGF is preferentially accumulated in the nuclei accompanying the transition of the cells from the $G_{0}$ to $G_{1}$ phase of the cell cycle. ${ }^{19}$ The nuclear bFGF may be involved in the regulation of cell proliferation through a direct interaction with DNA or through activation of nuclear protein kinases. ${ }^{82021}$ In addition, a nuclear translocation was essential for aFGF to stimulate cell proliferation since the mutant aFGF, which lacks the sequence for nuclear translocation, cannot stimulate DNA synthesis and mitosis. ${ }^{22}$ Together with the above findings, the present results indicated that the nuclear expression of bFGF is associated with a degree of proliferation rather than being a disease specific mechanism.

It has been shown that basement membranes and extracellular matrix (ECM) bind bFGF through heparan sulphate and heparin-like molecules and act as storage sites for bFGF. ${ }^{823-25}$ Heparin or heparin-like substitute prevents bFGF from proteolytic degradation. ${ }^{26}$ Furthermore, Yayon et al reported in their study that the binding to heparan sulphate is required for binding to the high affinity bFGF receptor. ${ }^{27}$ It seems that when cells are injured, the stored bFGF is free from the ECM either by the degradation of ECM by proteolytic enzymes released from the injured cells or competitively replaced by incoming heparin from ECM. ${ }^{11}$ In the present study, bFGF was not detectable along the basement membranes of synovial lining cells and vascular endothelial cells which contained bFGF. Considering that $\mathrm{RA}$ and $\mathrm{OA}$ are characterised by the active proliferation of synovial lining cells, these results may support the idea that bFGF synthesised in these cells is utilised by themselves as an autocrine growth factor. ${ }^{28} 29$ To support this, further studies are required.

We thank Dr K Nishikawa, (Second Division of Biochemistry, Kanazawa Medical College), who donated the anti-bFGF monoclonal antibody, and $\mathrm{Dr}$ Ohsato (Ophthalmology, Fukuoka University School of Medicine) for his helpful suggestions.

1 Wilder R L, Lafyatis R, Roberts A B, et al. Transforming growth factor- $\beta$ in rheumatoid arthritis. Ann NY Acad Sci growth factor- $\beta$ in rh

2 Goddard D H, Grossman S L, Williams W V, et al. Regulation of synovial cell growth. Arthritis Rheum 1992; 35: 1296-1303.

3 Remmers E F, Sano H, Lafyatis R, Case J P, et al. Production of platelet derived growth factor $\mathrm{B}$ chain (PDGF-B/c-sis) mRNA and immunoreactive PDGF B-like polypeptide by rheumatoid synovium: coexpression with heparin binding acidic fibroblast growth factor-1. I Rheumatol 1991; 18: 7-13.

4 Butler D M, Leizer T, Hamilton J A. Stimulation of human synovial fibroblast DNA synthesis by platelet-derived 1989; 142: 3098-103.

5 Reuterdahl C, Tingström A, Terracio L, Funa K, Heldin C $\mathrm{H}$, Rubin $\mathbf{K}$. Characterization of platelet-derived growth factor $\beta$-receptor expressing cells in the vasculature of factor $\beta$-receptor expressing cells in the vasculature of
human rheumatoid synovium. Lab Invest 1991; 64: human

6 Melnyk V O, Shipley G D, Sternfeld M D, Sherman L, Rosenbaum J T. Synoviocytes synthesize, bind, and respond to basic fibroblast growth factor. Arthritis Rheum 1990; 33: 493-500. 
7 Sano H, Forough R, Maier J A M, et al. Detection of high level of heparin binding growth factor-1 (acidic fibroblast growth factor) in inflammatory arthritic joints. $f$ Cell Biol 1990; 110: 1417-26.

8 Burgess $\mathrm{W} \mathrm{H}$, Maciag T. The heparin-binding (fibroblast) growth facto

9 Muthukrishnan L, Warder E, McNeil P L. Basic fibroblast growth factor is efficiently released from a cytosolic growth factor is efficiently released from a cytosolic storage site through plasma membrane disrupt

10 Mignatti P, Morimoto T, Rifkin D B. Basic fibroblast growth factor, a protein devoid of secretary signal sequence, is released by cells via a pathway independen of the endoplasmic reticulum-Golgi complex. $\mathcal{f} \mathrm{Cell}$ Physiol 1992; 151: 81-93.

11 Eguchi K, Migita K, Nakashima M, et al. Fibroblast growth factors released by wounded endothelial cells stimulate proliferation of synovial cells. $f$ Rheumatol 1992; 19: 1925-32.

12 Arnett F C, Edworthy S M, Bloch D A, et al. The American rheumatism association 1987 revised criteria for the classification of rheumatoid arthritis. Arthritis Rheum 1988; 31: 315-24.

13 Abraham J A, Whang J L, Tumolo A, et al. Human basic fibroblast growth factor: nucleotide sequence and genomic organization. $E M B O$ f $1986 ; 5 ; 2523-8$

14 Cooke N E, Coit D, Weiner R I, Baxter J D, Martial J A Structure of cloned DNA complementary to rat prolactin messenger RNA. F Biol Chem 1980; 255: 6502-10.

15 Koji T, Nakane P K. Localization in situ of specific mRNA using thymine-thymine dimerized DNA probes. Acta Pathol fpn 1990; 40: 793-807.

16 Nakane P K, Moriuchi T, Koji T, Tanno M, Abe K. In situ localization of mRNA using thymine-thymine dimerized cDNA. Acta Histochem Cytochem 1987; 20: 229-43.

17 Matsuzaki K, Yoshitake Y, Matuo Y, Sasaki H, Nishikawa K. Monoclonal antibodies against heparin-binding factor IV basic fibroblast growth factor that block its biological IV basic fibroblast growth factor that block its biological activity: invalidity of the antibodies for tumor

18 Dell'Era P, Presta M, Ragnotti G. Nuclear localization of endogenous basic fibroblast growth factor in cultured endothelial cells. Exp Cell Res 1991; 192: 505-10.
19 Bouche G, Gas N, Prats H, et al. Basic fibroblast growth factor enters the nucleolus and stimulates the transcription of ribosomal genes in ABAE cells undergoing $\mathrm{G}_{0} \notin \mathrm{G}_{1}$ transition. Natl Acad Sci USA 1987 ; 84: $6770-4$.

20 Huang S S, Huang J S. Association of bovine brain-derived growth factor receptor with protein tyrosine kinase growth factor receptor with 7 Biol Chem 1986; 261: 9568-71.

21 Coughlin S R, Barr P J Cousens L S, Fretto L J, Williams L T. Acidic and basic fibroblast growth factor stimulate tyrosine kinase activity in vivo. $\mathcal{f}$ Biol Chem 1988; 263: tyrosine

22 Imamura $\mathrm{T}$, Engleka $\mathrm{K}$, Zhan $\mathrm{X}$, et al. Recovery of mitogenic activity in a growth factor mutant with a nuclear translocation sequence. Science 1990; 249: 1567-70.

23 Vlodavsky I, Folkman J, Sullivan R, et al. Endothelial cellderived basic fibroblast growth factor: synthesis and deposition into subendothelial extracellular matrix. Proc Natl Acad Sci USA 1987; 84: 2292-6.

24 Folkman J, Klagsbrun M, Sasse J, Wadzinski M, Ingber D, Vlodavsky I. A heparin-binding angiogenic protein-basic fibroblast growth factor is stored within basement membrane. Am $f$ Pathol 1988; 130: 393-400.

25 Klagsbun $M$ The affinity of fibroblast growth facto Klagsbrun $M$. The affinity of fibroblast growth factor
(FGFs) for heparin; FGF-heparan sulfate interactions in cells and extracellular matrix. Curr Opin Cell Biol 1990; 2: 857-63.

26 Saksela O, Moscatelli D, Sommer A, Rifkin D B. Endothelial cell-derived heparan sulfate binds basic fibroblast growth factor and protects it from proteolytic degradation. f Cell Biol 1988; 107: 743-51.

27 Yayon A, Klagsbrun M, Esco J D, Leder P, Ornitz D M Cell surface, heparin-like molecules are required for binding of basic fibroblast growth factor to its high affinity receptor. Cell 1991; 64: 841-8.

28 Sato Y, Rifkin D B. Autocrine activities of basic fibroblast growth factor: regulation of endothelial cell movement,
plasminogen activator synthesis, and DNA synthesis. $\mathcal{f}$ Cell Biol 1988; 107: 1199-205.

29 Yayon A, Klagsbrun $M$. Autocrine regulation of cell growth and transformation by basic fibroblast growth factor Cancer Metastasis Rev 1990; 9: 191-202. 